\title{
Use of aqueous extract of noni in extender for sheep semen freezing
}

[Utilização do extrato aquoso de noni em diluente para congelação de sêmen ovino]

\author{
A.L.C. Nascimento ${ }^{1}$, A.D.F. Santos ${ }^{1}$, H.C. Azevedo ${ }^{2}$, J.M.D.S. Velarde ${ }^{3}$, \\ C.A. Lima ${ }^{1}$, M.A. Pereira ${ }^{1}$, G.O. Pinheiro ${ }^{1}$, L.C. Gomes ${ }^{1}$ \\ ${ }^{1}$ Universidade Federal de Sergipe - Aracaju, SE \\ ${ }^{2}$ Embrapa Tabuleiros Costeiros - Aracaju, SE \\ ${ }^{3}$ Universidade Federal da Bahia - Salvador, BA
}

\begin{abstract}
The study aimed to evaluate the action of aqueous extract of noni in an extender for sheep semen freezing. Treatments differed in inclusion of aqueous extract of noni in the extender: T1 - no addition; T2 $-24 \mu \mathrm{g} / \mathrm{mL} ; \mathrm{T} 3-72 \mu \mathrm{g} / \mathrm{mL}$; and $\mathrm{T} 4-120 \mu \mathrm{g} / \mathrm{mL}$. Ejaculates were collected, diluted in the four treatments, and frozen. After thawing, the semen was subjected to a thermoresistance test and evaluated for subjective motility, vigor, membrane integrity assessment by hypo-osmotic swelling test, live-dead assay, computer-assisted sperm analysis and the status of sperm capacitation and acrosome reaction. Data were subjected to ANOVA, and then to Student Newman Keuls's test at 5\% significance level. In the thermoresistance test after two hours of incubation, motility in T4 $(120 \mu \mathrm{g} / \mathrm{mL})$ was lower than in the other treatments, with no differences in the HoS test in either diluted semen or in the semen evaluated immediately post-thawing, while for the other times, treatments showed similar responses. Regarding the motility parameters, a difference was observed for progressive motility, curvilinear velocity, average path velocity, and amplitude of lateral head displacement. As to the sperm capacitation status, a difference was observed between treatments for the sperm capacitated with intact acrosome.
\end{abstract}

Keywords: concentrations, lipid peroxidation, plasma membrane, spermatozoon

\section{RESUMO}

Este estudo teve como objetivo avaliar a ação do extrato aquoso de noni em diluente para congelação de sêmen de carneiro. Os tratamentos diferiram quanto à inclusão de extrato aquoso de noni ao meio diluidor em: T1- sem adição de extrato; T2- $24 \mu \mathrm{g} / \mathrm{mL} ; T 3-72 \mu \mathrm{g} / \mathrm{mL}$ e $120 \mu \mathrm{g} / \mathrm{mL}$. Por meio de vagina artificial, 16 ejaculados foram coletados, diluídos entre os quatro tratamentos e congelados. Após o descongelamento, o sêmen foi submetido ao teste de termorresistência e avaliado quanto à motilidade subjetiva, ao vigor espermático, à integridade de membrana pelo teste hiposmótico, bem como ao teste supravital, à análise de sêmen assistida por computador (CASA) e ao status de capacitação espermática e de reação acrossomal. Os dados foram submetidos a uma análise de variância, seguida pelo teste de Student-Newman-Keuls com 5\% de significância. No teste de termorresistência, após duas horas de incubação, a motilidade do T4 $(120 \mu \mathrm{g} / \mathrm{mL})$ apresentou-se inferior aos demais tratamentos. Não houve diferença significativa no teste HOS tanto para o sêmen diluído quanto para o sêmen avaliado imediatamente pós-descongelação; para as demais horas, os tratamentos apresentaram comportamento semelhante. Para os parâmetros de cinética, foi observada diferença estatística para motilidade progressiva, velocidade curvilinear, velocidade do percurso médio e amplitude de deslocamento lateral da cabeça. Quanto ao estado de capacitação espermática, observou-se diferença entre os tratamentos para espermatozoide capacitado com acrossomo intacto.

Palavras-chave: concentrações, espermatozoide, lipoperoxidação, membrana plasmática

Recebido em 4 de abril de 2017

Aceito em 16 de dezembro de 2017

E-mail: annalauren.zootecnia@gmail.com 


\section{INTRODUCTION}

The semen freezing process impairs the sperm membranes in many ways, which may be due to the increased lipid peroxidation. As a result, the sperm cell undergoes oxidative damage caused by the imbalance between antioxidant substances and physiological concentrations of oxidants resulting from the reduced total antioxidant capacity of the semen and increased production of reactive oxygen species (Guerra et al., 2004).

Studies conducted in the last few years have shown that these imbalances between oxidant and antioxidant substances negatively affect the cell energy metabolism and the motility, viability, and integrity of the sperm cell DNA (Maia et al., 2009; Câmara and Guerra, 2011). Naturally, spermatozoa and the semen plasma have an antioxidant defense system that plays a key role in sperm viability. However, when the semen is diluted for freezing, the efficiency this antioxidant defense system is reduced (Câmara and Guerra, 2011).

Thus, for better sperm viability post-thawing, substances with antioxidant activity must be included in extenders aiming to provide balance to the activity of oxidants produced during preservation procedures.

Noni (Morindacitrifolia) has been studied for its antioxidant, anti-inflammatory, and anticarcinogenic properties(Chan-Blanco et al., 2006; Barros et al., 2008; Silva et al., 2012) for being considered a fruit with antioxidant potential and probable free-radical eliminating effect, which can result from compounds contained in different parts of the plant, especially the fruit pulp, which has a large amount of vitamin C. Chan-Blanco et al. (2006), Barros et al. (2008), and Silva et al. (2012) studied noni and found different, but high levels of vitamin $\mathrm{C}$ in the fruit pulp: $316,385.16$, and $101.41 \mathrm{mg}^{1} 100 \mathrm{~g}^{-1}$, respectively.

This study aimed to evaluate the inclusion of different concentrations of aqueous extract of noni in an extender for sheep semen freezing, focusing on sperm motility and membrane integrity.

\section{MATERIAL AND METHODS}

The experiment was carried out from September 2014 to January 2015, in the Sheep Farming
Section of the Central Vivarium at the Federal University of Sergipe, located in São CristóvãoSE, Brazil $\left(11^{\circ} 00^{\prime} 54^{\prime \prime}\right.$ S $37^{\circ} 12^{\prime} 21^{\prime \prime} \mathrm{W} ; 30.0 \mathrm{~m}$ altitude). This study was approved by the Animal Ethics Committee (Protocol 11/12/2014).

Frozen and thawed semen analyses were performed in the Animal Reproduction Laboratory at the Federal University of Sergipe and in the Laboratory of Animal Reproduction Biotechnology (LABRA) at EMBRAPA, in Aracaju city.

Two Santa Inês sires aged 12 to 24 months, proven to be fertile and subjected to previous andrological examination, were utilized in the trial. During the experimental period, the animals remained confined in groups surrounded by fences, separated from females, and fed elephant grass (PennisetumPurpureum) and a commercial concentrate. Mineral salt and water were supplied ad libitum.

Treatments differed based on the results of Nascimento et al. (2016) as to the inclusion of extract of noni fruit, as follows: Treatment 1 (T1) -semen diluted in extender based on Tris-egg yolk-glycerol without aqueous extract of noni pulp; T2 - $24 \mu \mathrm{g} / \mathrm{mL}$ aqueous extract of noni fruit added to the extender; T3 - $72 \mu \mathrm{g} / \mathrm{mL}$ aqueous extract of noni fruit added to the extender; and $\mathrm{T} 4-120 \mu \mathrm{g} / \mathrm{mL}$ aqueous extract of noni fruit added to the extender. The adapted methodology of Kutvoelgyi (2008) was used for the preparation of the extract.

A Tris-based extender was used, composed of standard solution containing $2.42 \mathrm{~g}$ Tris, $1.50 \mathrm{~g}$ citric acid monohydrate, $1.25 \mathrm{~g}$ glucose, $0.0134 \mathrm{~g}$ streptomycin sulfate, $20 \mathrm{~mL}$ egg yolk, $4 \mathrm{~mL}$ glycerol, and $100 \mathrm{~mL}$ tri-distilled water (Salamon and Maxwell, 2000).

Two collections were performed daily - one per animal -, for eight days, totaling 16 ejaculates. Animals were subjected to semen collection using an artificial vagina previously heated to $42^{\circ} \mathrm{C}$, whose mannequin was a female in estrus induced by application of $1.0 \mathrm{mg}$ estradiol benzoate (Estrogin ${ }^{\circledR}$, Farmavet) on the first day and $0.5 \mathrm{mg}$ whenever the female was less receptive to the male. 
Following the methodology proposed by Maia et al. (2008), after collection, the semen was transferred to the laboratory to measure its volume by direct reading on the very collection tube and kept in a water bath at $32^{\circ} \mathrm{C}$ until dilution. An aliquot of semen was taken and placed on a blade heated to $37^{\circ} \mathrm{C}$ for evaluation of mass motility (from 0 to 5), and on blade and cover slip heated to $37^{\circ} \mathrm{C}$ for evaluation of motility ( 0 to $100 \%$ ) and vigor ( 0 to 5$)$, all by optical microscopy under 20x magnification.

For the evaluation of the semen concentration, $10 \mu \mathrm{L}$ of semen were added to an Eppendorf ${ }^{\circledR}$ microtube containing $2 \mathrm{~mL}$ buffered formalsaline solution, from which aliquots were taken for immediate evaluation of sperm concentration and later morphological analysis in moist chamber and stained blade. The sperm concentration $\left(\times 10^{6} \mathrm{sptz} / \mathrm{mL}\right)$ was determined by counting the cells in a Neubauer chamber by optical microscopy under 40x magnification, with the number of insemination doses determined at a concentration of $100 \times 10^{6} \mathrm{sptz} / \mathrm{mL}$.

The semen was divided into four aliquots of equal volumes, diluted according to the different treatments, and stored in $0.25 \mathrm{~mL}$ straws, followed by refrigeration in a Minitüb ${ }^{\circledR} 518 \mathrm{C}$ refrigerator (Minituib do Brasil Ltda), where the straws were placed on plastic baby bottles containing alcohol, aiming to control the chilling from 32 to $5^{\circ} \mathrm{C}$ for a period of two hours. Next, straws were transferred to a 37-L Styrofoam box containing 5.5L liquid nitrogen $\left(\mathrm{N}_{2} \mathrm{~L}\right)$, where they were exposed to $\mathrm{N}_{2} \mathrm{~L}$ vapor for $20 \mathrm{~min}$ in the horizontal position, at $3 \mathrm{~cm}$ from the nitrogen slide, and then immediately submerged in the $\mathrm{N}_{2} \mathrm{~L}$, packed in racks, and stored in cryogenic liquid containers with liquid nitrogen at $-196^{\circ} \mathrm{C}$.

Sperm viability was evaluated by live-dead assay. For this, semen smear was stained with eosin/nigrosine. A $10-\mu \mathrm{L}$ semen aliquot was added to $500 \mu \mathrm{L} \mathrm{x}$-cell ${ }^{\circledR}$, and then $5 \mu \mathrm{L} \mathrm{x}$-cell ${ }^{\circledR}+$ semen were added to $5 \mu \mathrm{L}$ eosin/nigrosine from where an aliquot was taken for the smear and subsequent count of 200 cells on a binocular microscope under 100x magnification. Results were expressed in total percentage of unstained (live) spermatozoa.
Aliquots were taken from the Eppendorf ${ }^{\circledR}$ tube containing semen + buffered formal-saline solution for analyses of head pathologies in smear stained with Instant-Prov $\mathrm{Kit}^{\circledR}$, whereas for morphological evaluation of tail and acrosome pathologies, we used the moist chamber technique (Hancock, 1956). For both analyses, 200 sperm cells were counted by phase-contrast microscopy under100x magnification.

The capacity of the extract to inhibit lipid peroxidation after thawing the semen during $30 \mathrm{~s}$ at $37^{\circ} \mathrm{C}$ was determined by monitoring the production of thiobarbituric acid reactive substances (TBARS) in a lipid-rich medium according to the protocol described by Silva et al. (2007). The protocol of Lapenna et al. (2001) was used to quantify the TBARS.

For the slow thermoresistance test (TRT), we followed a methodology that was based on those described by Henry and Neves (1998), and Gonçalves et al. (2008). Semen doses were thawed at $37^{\circ} \mathrm{C}$ for 30 s, packed in Eppendorf $f^{\circledR}$ microtubes $(1.5 \mathrm{~mL})$, covered with one drop of previously heated mineral oil, and incubated at $37^{\circ} \mathrm{C}$ for $2 \mathrm{~h}$, simulating the presence of spermatozoa in the feminine genital tract. Sperm motility and vigor were evaluated by optical microscopy, under 20x magnification, at three times: zero time $(0 \mathrm{~h})$, immediately after thawing, and every hour after thawing ( $1 \mathrm{~h}$ and $2 \mathrm{~h}$ ). During TRT, the live-dead assay was also performed by staining the smear with eosin/nigrosine and subsequent count of 200 cells on a binocular microscope under 100x magnification. The result was expressed in total percentage of unstained (live) spermatozoa. This test was conducted immediately after thawing the semen (0h) and after two hours of incubation at $37^{\circ} \mathrm{C}(2 \mathrm{~h})$.

Semen hypo-osmotic swelling test was performed after dilution in the respective treatments, before chilling, and during the thermoresistance test (TRT). For this, $1.5 \mathrm{~mL}$ of a hypo-osmotic solution with $125 \mathrm{mOsm} / \mathrm{L}$ osmolarity (Fonseca et al., 2005) were kept in a microtube in a water bath at $37^{\circ} \mathrm{C} ; 10 \mu \mathrm{L}$ fresh diluted semen, thawed at (times) 0,1 , and $2 \mathrm{~h}$, were added and incubated for one hour. After the specified time, a sample was placed between a blade and a coverslip, and 200 cells were counted on a phase-contrast microscope 
under100x magnification and the result was expressed as percentage of spermatozoa with folded tail, subtracting double-tail defects related to pathology.

Sperm motility was assessed using computerassisted sperm analysis (CASA) set up for sheep, as described by Azevedo (2006). Three-milliliter samples of diluted semen in a test solution $(\mathrm{pH}$ 6.8 and $320 \mathrm{mOsm}$ ) were transferred to a previously heated $\left(37^{\circ} \mathrm{C}\right)$ Makler ${ }^{\circledR}$ chamber. Images were captured at four fields selected at random from the same central point. Evaluated motility parameters were: total motility (\%), progressive motility $(\%)$, path velocity $(\mu \mathrm{m} / \mathrm{s})$, curvilinear velocity $(\mu \mathrm{m} / \mathrm{s})$, amplitude of lateral head $(\mu \mathrm{m})$, straightness $(\%)$, and linearity $(\%)$.

The plasma membrane integrity (PMI) was analyzed by combining the fluorochromes SYBR Green and propidium iodide (17011LIVE/DEAD, Molecular Probes Inc., Eugene, OR, USA), adapting the methodology utilized by Garner e Johnson (1995). A 50- $\mu \mathrm{L}$ aliquot of semen sample diluted in a test solution was placed in microtubes previously heated to $37^{\circ} \mathrm{C}$, to which $2.5 \mu \mathrm{L} S Y B R$ Green were added, and the sample was kept incubated for $5 \mathrm{~min}$. After this period, $5 \mu \mathrm{L}$ propidium iodide and $1 \mu \mathrm{L}$ $1 \%$ glutaraldehyde were added and the sample was kept incubated for another five minutes, and then read. A total of 200 cells was evaluated on a fluorescence microscope with objective lens under $1,000 \mathrm{x}$ magnification; sperm were classified as having intact plasma membrane when they showed the head region stained only green or in any portion red.

The status of capacitation and acrosome reaction of the spermatozoa was analyzed using chlortetracycline (CTC), described in the methodology of Gillan et al.(1997) adapted by Azevedo (2006). Semen samples were diluted in $1,000 \mu \mathrm{L}$ buffered phosphate saline (PBS) solution without calcium (Barth and Oko, 1989), pre-heated to $37^{\circ} \mathrm{C}$ and subjected to mild centrifugation at $400 \mathrm{~g}$ for $4 \mathrm{~min}$. Next, the supernatant was carefully removed, and the semen pellet was resuspended with $150 \mu \mathrm{L}$ PBS. A $5-\mu \mathrm{L}$ aliquot was removed from the solution produced from resuspension and added to a microtube containing $20 \mu \mathrm{L}$ of $1 \mathrm{mMCTC}$ solution. The mixture was homogenized and left incubated for $15 \mathrm{~min}$. Next, a $12-\mu \mathrm{L}$ aliquot was taken for reading under blade and cover slip on a fluorescence microscope under1000x magnification. A total of 200 cells were analyzed and classified as: F - not capacitated with intact acrosome, uniform distribution of yellow fluorescence all over head with presence or absence of brighter dotted line in the equatorial region; B - capacitated with intact acrosome, fluorescence in the anterior region of the head, no fluorescence in the post-acrosomal region; or RA - with reacted acrosome and absence of fluorescence in the region of the head corresponding to the acrosome.

The experiment was conducted in a completely randomized design (CRD) with four treatments and 16 replications per treatment. For statistical analysis of the evaluated characteristics, we used the statistical package Statistical Analysis System (SAS, 2002), applying the PROC MEANS procedure for descriptive analysis and GLM procedure with the Student Newman Keuls (SNK) test at $5 \%$ for the comparison of sperm parameters between the different experimental groups. All variables were subjected to SaphiroWilk normality test. However, the variables hypo-osmotic swelling test, total and progressive motility, membrane integrity, and vigor were considered abnormal. These were transformed into normal using the Box-Cox method (Box e Cox, 1964), and applying the PROC MEANS procedure for descriptive analysis and GLM procedure with the Student Newman Keuls (SNK) test at $5 \%$.

\section{RESULTS}

The Table 1, referring to the fresh sheep semen characteristics obtained in this experiment. As: volume $(\mathrm{mL})$, mass motility, motility, vigor, membrane integrity (live and dead), plasma membrane integrity (HoS) and total pathologies.

Treatments T1 $(0 \mu \mathrm{g} / \mathrm{mL}$ of aqueous extract of noni pulp) and T3 $(72 \mu \mathrm{g} / \mathrm{mL}$ of aqueous extract of noni pulp) best prevented lipid peroxidation in the spermatozoa post-thawing, with lower malonaldehyde production (Figure 1). Of the treatments with aqueous extract of noni, T3 $(72 \mu \mathrm{g} / \mathrm{mL})$ best prevented lipid peroxidation. We can thus infer that the ideal concentration of aqueous extract of noni to be added to the extender for reducing lipid peroxidation is between 24 and $124 \mu \mathrm{g} / \mathrm{mL}$. 
Table 1. Physical and morphological characteristics of fresh sheep semen before distribution in the treatments

\begin{tabular}{cc} 
Parameter & Mean values and standard deviation \\
\hline Volume (mL) & $0.73 \pm 0.18$ \\
Mass motility & $4.21 \pm 0.44$ \\
Motility (\%) & $80.00 \pm 0.02$ \\
Vigor (0-5) & $3.09 \pm 0.20$ \\
Membrane integrity (live and dead, \%) & $85.16 \pm 7.72$ \\
Plasma membrane integrity (HoS) & $58.19 \pm 14.80$ \\
Total pathologies (\%) & $6.93 \pm 3.86$ \\
\hline
\end{tabular}

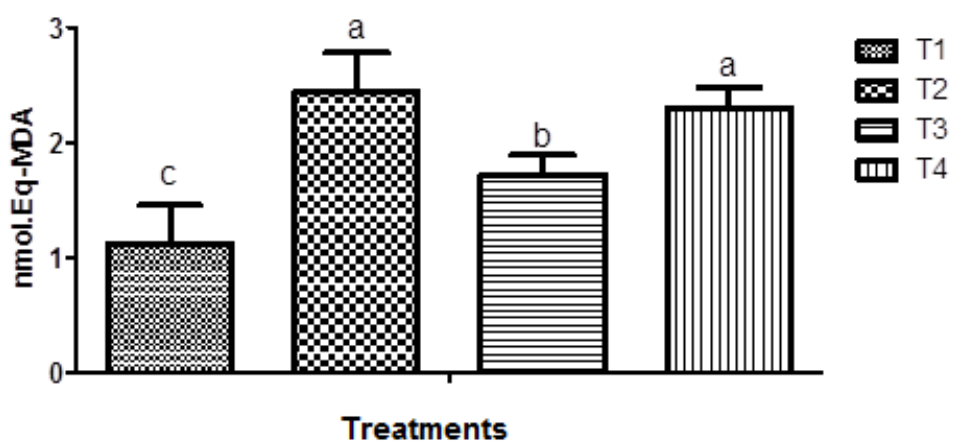

Figure 1. In vitro lipid peroxidation prevention capacity of different concentrations of aqueous extract of noni in thawed semen expressed as malonaldehyde production in nmol. Concentration of aqueous extract of noni pulp: $\mathrm{T} 1=0 \mu \mathrm{g} / \mathrm{mL} ; \mathrm{T} 2=24 \mu \mathrm{g} / \mathrm{mL} ; \mathrm{t} 3=72 \mu \mathrm{g} / \mathrm{mL} ; \mathrm{T} 4=120 \mu \mathrm{g} / \mathrm{mL}$.

Values for motility, vigor, and live-dead assay results are described in Table 2. Immediately after thawing, the motility of treatments $\mathrm{T} 1$ $(0 \mu \mathrm{g} / \mathrm{mL}$ of aqueous extract of noni pulp; $36.8 \pm 5.8)$ and $\mathrm{T} 2(24 \mu \mathrm{g} / \mathrm{mL}$ of aqueous extract of noni pulp; $37.8 \pm 5.9$ ) was significantly higher than that of treatments $3(72 \mu \mathrm{g} / \mathrm{mL}$ of aqueous extract of noni pulp) and $4(120 \mu \mathrm{g} / \mathrm{mL}$ of aqueous extract of noni pulp), which averaged $31.3 \pm 6.2$ and $24.9 \pm 7.7$, respectively.
As to vigor, there were no differences between the treatments immediately after thawing $(\mathrm{P}>0.05)$. After one hour of incubation (1h), T4 $(120 \mu \mathrm{g} / \mathrm{mL})$, which averaged $2.1 \pm 1.0$, was significantly inferior to treatments $\mathrm{T} 1(0 \mu \mathrm{g} / \mathrm{mL})$ andT2 $(24 \mu \mathrm{g} / \mathrm{mL})$, which averaged $2.7 \pm 0.5$ and $2.8 \pm 0.4$, respectively. In two hours of incubation, the highest results for vigor were obtained in T1 $(0 \mu \mathrm{g} / \mathrm{mL})$ andT2 $(24 \mu \mathrm{g} / \mathrm{mL})$, which did not differ $(\mathrm{P}>0.05)$.

Table 2. Motility and vigor of thawed semen during the slow thermoresistance test (TRT) and percentage of spermatozoa unstained in the live-dead staining assay thawed and at the end of TRT in extender containing different concentrations of aqueous extract of noni fruit added to the extender at three times (0h, 1h, and $2 \mathrm{~h})$

\begin{tabular}{cccccc}
\hline \multicolumn{5}{c}{ Concentration of aqueous extract of noni pulp } \\
\hline Parameter & Time & T1 $(0 \mu \mathrm{g} / \mathrm{mL})$ & T2 $(24 \mu \mathrm{g} / \mathrm{mL})$ & T3 $(72 \mu \mathrm{g} / \mathrm{mL})$ & $\mathrm{T} 4(120 \mu \mathrm{g} / \mathrm{mL})$ \\
\hline \multirow{2}{*}{ Motility (\%) } & Oh & $36.8 \pm 5.8^{\mathrm{a}}$ & $37.8 \pm 5.9^{\mathrm{a}}$ & $31.3 \pm 6.2^{\mathrm{b}}$ & $24.9 \pm 7.7^{\mathrm{c}}$ \\
& $1 \mathrm{~h}$ & $29.7 \pm 10^{\mathrm{a}}$ & $31.8 \pm 10.7^{\mathrm{a}}$ & $24.5 \pm 8.7^{\mathrm{a}}$ & $14.4 \pm 9.1^{\mathrm{b}}$ \\
& $2 \mathrm{~h}$ & $20.8 \pm 11.6^{\mathrm{ab}}$ & $22.6 \pm 9.7^{\mathrm{a}}$ & $13.8 \pm 7.3^{\mathrm{bc}}$ & $8.3 \pm 6.8^{\mathrm{c}}$ \\
Vigor & Oh & $3.0 \pm 0.1^{\mathrm{b}}$ & $2.9 \pm 0.3$ & $2.8 \pm 0.4$ & $2.7 \pm 0.5$ \\
& $1 \mathrm{~h}$ & $2.7 \pm 0.5^{\mathrm{a}}$ & $2.8 \pm 0.4^{\mathrm{a}}$ & $2.5 \pm 0.8^{\mathrm{ab}}$ & $2.1 \pm 1.0^{\mathrm{b}}$ \\
Live-dead & $2 \mathrm{~h}$ & $2.4 \pm 0.5^{\mathrm{a}}$ & $2.5 \pm 0.5^{\mathrm{a}}$ & $1.9 \pm 0.8^{\mathrm{ab}}$ & $1.6 \pm 0.8^{\mathrm{b}}$ \\
staining (\%) & 0h & $37.6 \pm 10.1^{\mathrm{a}}$ & $24.3 \pm 10.5^{\mathrm{b}}$ & $17.3 \pm 8.2^{\mathrm{bc}}$ & $13.7 \pm 6.3^{\mathrm{c}}$ \\
\hline
\end{tabular}

Different letters in the same row differ statistically according to Student Newman Keuls's test $(\mathrm{P}<0.05)$. 
A difference was detected for percentage of spermatozoa stained in the live-dead assay immediately after thawing, in which $\mathrm{T} 1$ $(0 \mu \mathrm{g} / \mathrm{mL})$ was superior than the other treatments; and the value of Live-dead staining decreases when the Concentration of aqueous extract of noni pulp increases. After two hours of incubation, the treatments $\mathrm{T} 1(0 \mu \mathrm{g} / \mathrm{mL})$ differed from each other $(\mathrm{P}<0.05), \mathrm{T} 3(72 \mu \mathrm{g} / \mathrm{mL})$, and T4 $(120 \mu \mathrm{g} / \mathrm{mL})$, whereas $\mathrm{T} 2(24 \mu \mathrm{g} / \mathrm{mL})$ did not differ from T1 $(0 \mu \mathrm{g} / \mathrm{mL})$. Overall, T4 $(120 \mu \mathrm{g} / \mathrm{mL})$ showed worse results for motility and vigor after thawing and TRT when compared with the other treatments. However, when assessed by live-dead assay, we could observe that the aqueous extract of noni at the concentration of $120 \mu \mathrm{g} / \mathrm{mL}$ allowed the maintenance of structural integrity to the membrane and sperm viability after thawing, with an average decrease of $2.8 \%$ intact spermatozoa $2 \mathrm{~h}$ after thawing.

There was no difference ( $\mathrm{P}>0.05$ ) between treatments for semen diluted and immediately after thawing (Oh) in the hypo-osmotic swelling test (Table 3). No differences were observed, either (P> 0.05), between treatments $\mathrm{T} 1$ $(0 \mu \mathrm{g} / \mathrm{mL}), \mathrm{T} 3(72 \mu \mathrm{g} / \mathrm{mL})$, and T4 $(120 \mu \mathrm{g} / \mathrm{mL})$ after one (1h) and two (2h) hours of incubation. Only T4 $(120 \mu \mathrm{g} / \mathrm{mL})$ was superior to $\mathrm{T} 2$ $(24 \mu \mathrm{g} / \mathrm{mL})$ after one hour of incubation, and only T3 $(72 \mu \mathrm{g} / \mathrm{mL})$ was superior to T2 $(24 \mu \mathrm{g} / \mathrm{mL})$ after two hours of incubation.

By the hypo-osmotic swelling test, it could be inferred that the plasma membrane of the spermatozoon became more preserved as the concentration of aqueous extract of noni in the extender was increased.

Table 3. Means and standard deviation for spermatozoa subjected to the hypo-osmotic swelling test (HOS) in diluted semen and TRT in extender with different concentrations of aqueous extract of noni

\begin{tabular}{ccccc}
\multirow{2}{*}{ Treatment } & \multirow{2}{*}{ Pre-thawing $\%$} & $0 \mathrm{~h}$ & TRT (hours) \\
\cline { 3 - 5 } & & $33.8 \pm 8.0$ & $30.9 \pm 11.2^{\mathrm{ab}}$ & $29.6 \pm 6.6^{\mathrm{ab}}$ \\
$\mathrm{T} 1(0 \mu \mathrm{g} / \mathrm{mL})$ & $60.0 \pm 16.7$ & $31.7 \pm 12.4$ & $26.6 \pm 9.0^{\mathrm{b}}$ & $26.9 \pm 9.5^{\mathrm{b}}$ \\
$\mathrm{T} 2(24 \mu \mathrm{g} / \mathrm{mL})$ & $51.6 \pm 13.9$ & $35.2 \pm 13.9$ & $35.3 \pm 10.6^{\mathrm{ab}}$ & $35.8 \pm 10^{\mathrm{a}}$ \\
$\mathrm{T} 3(72 \mu \mathrm{g} / \mathrm{mL})$ & $58.3 \pm 13.0$ & $38.2 \pm 8.6$ & $38.4 \pm 13.6^{\mathrm{a}}$ & $31.2 \pm 8.8^{\mathrm{ab}}$ \\
$\mathrm{T} 4(120 \mu \mathrm{g} / \mathrm{mL})$ & $63.5 \pm 15.0$ &
\end{tabular}

Different letters in the same column differ statistically according to Student Newman Keuls's test $(\mathrm{P}<0.05)$.

Table 4 shows the results referring to the motility parameters of semen after thawing. Total motility in the different treatments did not differ $(\mathrm{P}>0.05)$. Sperm cells differed for progressive motility (PM), curvilinear velocity (CLV), average path velocity (APV), and amplitude of lateral head displacement (ALH) at the different concentrations of aqueous extract of noni $(\mathrm{P}<$
0.05). For PM, control treatment had better results than the others, with no differences detected between treatments $\mathrm{T} 2(24 \mu \mathrm{g} / \mathrm{mL}), \mathrm{T} 3$ $(72 \mu \mathrm{g} / \mathrm{mL})$, and $\mathrm{T} 4 \quad(120 \mu \mathrm{g} / \mathrm{mL})$. For the variables CLV and APV, T2 $(24 \mu \mathrm{g} / \mathrm{mL})$ showed a similar result to control; for ALH, T4 $(120 \mu \mathrm{g} / \mathrm{mL})$ was inferior to the other treatments.

Table 4. Motility parameters post-thawing of sheep semen frozen in extender containing different concentrations of aqueous extract of noni

\begin{tabular}{lcccc}
\hline \multicolumn{5}{c}{ Concentration of aqueous extract of noni pulp } \\
\hline \multicolumn{1}{c}{ Parameter } & $\mathrm{T} 1(0 \mu \mathrm{g} / \mathrm{mL})$ & $\mathrm{T} 2(24 \mu \mathrm{g} / \mathrm{mL})$ & $\mathrm{T} 3(72 \mu \mathrm{g} / \mathrm{mL})$ & $\begin{array}{c}\mathrm{T} 4(120 \\
\mu \mathrm{g} / \mathrm{mL})\end{array}$ \\
\hline Total motility $(\%)$ & $48.2 \pm 14.9$ & $35.6 \pm 17.4$ & $39.0 \pm 15.0$ & $32.9 \pm 16.0$ \\
Progressive motility $(\%)$ & $26.9 \pm 9.7^{\mathrm{a}}$ & $20.1 \pm 12.6^{\mathrm{b}}$ & $20.7 \pm 10.8^{\mathrm{b}}$ & $15.5 \pm 9.2^{\mathrm{b}}$ \\
Curvilinear velocity $(\mu / \mathrm{s})$ & $194.5 \pm 20.7^{\mathrm{a}}$ & $186.6 \pm 34.1^{\mathrm{a}}$ & $176.6 \pm 19.4^{\mathrm{b}}$ & $170.3 \pm 24.7^{\mathrm{b}}$ \\
Straight-line velocity $(\mu / \mathrm{s})$ & $97.2 \pm 13.3$ & $97.2 \pm 13.3$ & $89.2 \pm 14.6$ & $84.6 \pm 16.2$ \\
Average path velocity $(\mu / \mathrm{s})$ & $121.5 \pm 12.8^{\mathrm{a}}$ & $121.5 \pm 12.8^{\mathrm{a}}$ & $111.8 \pm 13.8^{\mathrm{b}}$ & $107.0 \pm 16.8^{\mathrm{b}}$ \\
Amplitude of lateral head displacement $(\%)$ & $2.7 \pm 0.4^{\mathrm{a}}$ & $2.7 \pm 0.4^{\mathrm{a}}$ & $2.5 \pm 0.3^{\mathrm{a}}$ & $2.3 \pm 0.4^{\mathrm{b}}$ \\
Straightness $(\%)$ & $79.8 \pm 7.5$ & $79.8 \pm 4.5$ & $79.5 \pm 4.9$ & $78.7 \pm 4.2$ \\
Linearity $(\%)$ & $49.9 \pm 3.3$ & $49.9 \pm 3.3$ & $50.4 \pm 5$ & $49.6 \pm 5.7$ \\
\hline
\end{tabular}

Different letters in the same row differ statistically according to Student Newman Keuls's test $(\mathrm{P}<0.05)$. 
Treatments did not differ as to plasma membrane integrity (PMI), for spermatozoa not capacitated with intact acrosome (F) and spermatozoa with reacted acrosome (RA) (P> 0.05) (Table 5). There was a difference $(\mathrm{P}<0.05)$ for spermatozoa capacitated with intact acrosome
(B), showing that the treatments containing aqueous extract of noni had a similar response to control treatment and that T2 $(24 \mu \mathrm{g} / \mathrm{mL})$ was superior to the treatment with the highest concentration of extract.

Table 5. Plasma membrane integrity and sperm capacitation (CTC) post-thawing of sheep semen diluted in different concentrations of aqueous extract of noni

\begin{tabular}{ccccc}
\hline \multicolumn{5}{c}{ Concentration of aqueous extract of noni pulp } \\
\hline Parameter & $\mathrm{T} 1(0 \mu \mathrm{g} / \mathrm{mL})$ & $\mathrm{T} 2(24 \mu \mathrm{g} / \mathrm{mL})$ & $\mathrm{T} 3(72 \mu \mathrm{g} / \mathrm{mL})$ & $\mathrm{T} 4(120 \mu \mathrm{g} / \mathrm{mL})$ \\
\hline PMI & $14.9 \pm 7.3$ & $11.8 \pm 6.2$ & $11.7 \pm 5.0$ & $10.9 \pm 5.7$ \\
F & $17.3 \pm 10.3$ & $12.2 \pm 10.3$ & $15.7 \pm 11.1$ & $13.3 \pm 7.5$ \\
B & $4.9 \pm 3.0^{\mathrm{ab}}$ & $5.4 \pm 3.0^{\mathrm{a}}$ & $4.5 \pm 3.9^{\mathrm{ab}}$ & $2.5 \pm 1.3^{\mathrm{b}}$ \\
RA & $77.8 \pm 10.8$ & $82.1 \pm 10.8$ & $80.0 \pm 13.3$ & $84.3 \pm 8.1$ \\
\hline
\end{tabular}

PMI - plasma membrane integrity; F - spermatozoa not capacitated with intact acrosome; B - spermatozoa capacitated with intact acrosome; RA - spermatozoa not capacitated with reacted acrosome.

Different letters in the same row differ statistically according to Student Newman Keuls's test $(\mathrm{P}<0.05)$.

\section{DISCUSSION}

The characteristics of the fresh semen obtained in this experiment agree with the values recommended by the Brazilian College of Animal Reproduction (Henry et al. 2013). After the freezing process, 40 to $50 \%$ of the spermatozoa become unable to fertilize (Watson, 2000), and hence the need for using good-quality ejaculates to obtain satisfactory fertilization levels.

Analyzing subjective motility after one hour of incubation, treatment $\mathrm{T} 4(120 \mu \mathrm{g} / \mathrm{mL}$ of aqueous extract of noni pulp) showed to be inferior to the others. Two hours after incubation, T2 $(24 \mu \mathrm{g} / \mathrm{mL}$ aqueous extract of noni) became similar to control treatment, displaying greater motility than the other treatments with addition of aqueous extract of noni.

Motility results observed after $1 \mathrm{~h}$ of incubation showed to be greater than those found by Peixoto et al. (2008), who froze sheep semen with addition of ascorbic acid and Trolox in Tris-yolk extender and found $20 \pm 5 \%$ and $15 \pm 5 \%$ motility for control group and the group that received with $600 \mu \mathrm{M} / \mathrm{L}$ ascorbic acid $(0.11 \mathrm{mg} / \mathrm{mL})$, respectively, and similar to those found by Santos et al. (2015), who compared a control extender for freezing sheep semen with extenders with different amounts of lyophilized noni pulp $(0.2346 \mathrm{~g}, 0.4692 \mathrm{~g}$, and $0.7038 \mathrm{~g})$ and obtained motility values $(\%)$ of $40.7 \pm 13.5,31.4 \pm 14.5$,
$33.3 \pm 12.9,22.1 \pm 16.1$ for control and the other treatments, respectively.

Vigor expresses the speed of movement of spermatozoa with progressive motility (Neves $e t$ al., 2008); thus, the low vigor shown by $\mathrm{T} 4$ $(120 \mu \mathrm{g} / \mathrm{mL}$ of aqueous extract of noni pulp) may be reflected in the progressive motility of this same treatment, compromising fertilization by these spermatozoa.

By the hypo-osmotic swelling test, it could be inferred that the plasma membrane of the spermatozoon became more preserved as the concentration of aqueous extract of noni in the extender was increased. These results were superior to those found by Penitente-Filho et al. (2014), who included different concentrations of vitamin $\mathrm{E}(25 \mu \mathrm{M}, 50 \mu \mathrm{M}$, and $100 \mu \mathrm{M})$ in goat semen. However, they were inferior to those obtained by Santos et al. (2015) after addition of the extender with different amounts of lyophilized noni pulp to thawed sheep semen. Based on this result obtained by Santos et al. (2015), it is suggested that lyophilized noni has a greater capacity to preserve the sperm plasma membrane than its aqueous extract.

Results for total motility (TM) and progressive motility (PM) were similar to those found by Maia et al. (2008), who did not observe significant differences after adding $6.25 \mathrm{mg} / \mathrm{mL}$ $(0.0935 \mathrm{U} / \mathrm{mL})$ catalase to the extender, and Silva (2013), who added $0.5 \mathrm{mg} / \mathrm{mL}$ of ascorbic acid to the extender. 
For the parameters curvilinear velocity (CLV) and straightness (STR), the results found in this study were higher than the $173.4 \pm 4.33$ and $77.1 \pm 1.56$, respectively, published by Sicherle (2007), who added catalase to the extender, and similar when the author added trolox (179.2 \pm 5.98 and $80.5 \pm 1.29)$. Regarding average path velocity (APV), amplitude of lateral head displacement (ALH), and straight-line velocity (SLV), the results of this study were also superior to those found by Corandin et al. (2013), who added $2.5 \mathrm{mM}$ cysteine to the extender. However, the linearity of the sperm diluted in extender with aqueous extract of noni was lower than that of the afore-mentioned studies. Therefore, aqueous extract of noni in extender showed to be similar to other substances defined as antioxidants.

Overall, we observed that increased concentrations of aqueous extract reduced the sperm travel speed. This result can be detrimental when it concerns the displacement of sperm towards the egg for fertilization.

Treatments did not differ to spermatozoa with reacted acrosome (RA). However, the number of spermatozoa with reacted acrosome (RA) was elevated in all tested treatments, and superior to the $27 \%, 51 \%$, and $54.1 \%$ found by Gillan et al. (1997), Azevedo (2006), and Sicherle (2007), respectively, working with sheep sperm.

After the semen freezing and thawing processes, the sheep sperm display the color patterns produced by chlortetracycline (CTC) typical of capacitated spermatozoa. According to the CTC patterns, the percentage of uncapacitated spermatozoa $(\mathrm{F})$ decreases, while the percentage of sperm capacitated (B and RA) with the reacted or intact acrosome increases (Perez et al., 1996; Gillan et al., 1997).

The plasma membrane integrity is considered important for the semen quality due to the inability of the sperm to restore it. This membrane acts in the cell metabolism, sperm capacitation, acrosome reaction, and union of spermatozoa to the egg surface (Neves et al., 2008). The cryopreservation process may lead to alterations in the membranes of sheep sperm, making it similar to the capacitated spermatozoon (Green and Watson, 2001; Thomas et al., 2006).
The acrosomal reaction has been used as an indicator of complete capacitation. Some researchers have stated that spermatozoa that undergo acrosomal reaction are more susceptible to denaturation of the nuclear DNA, with a direct relationship between the condensation of chromatin and fertilizing capacity of sperm (Watson, 1995; Peris et al., 2004). This high number of spermatozoa with reacted acrosome (RA) might have been caused by the freezing process rather than the action of substances with antioxidant property.

\section{CONCLUSION}

The inclusion of aqueous extract of noni in a Tris-yolk-glycerol-based extender for sheep semen freezing, did not improve of spermatic parameters. However, the aqueous extract of noni maintained the function and integrity of the sperm plasma membrane.

\section{REFERENCES}

AZEVEDO, H.C. Integridade e funcionalidade dos espermatozóides ovinos submetidos à criopreservação após a incorporação de colesterol, desmosterol, ácido oléico-linoléico e alfa-lactoalbumina. 2006. 192f. (Doutor em Reprodução Animal). Escola de Medicina Veterinária e Zootecnia, Universidade Estadual Paulista, Jaboticabal, SP.

BARROS, S.P.N.B.; MAIA, G.A.; BRITO, E.S. et al. Caracterização físico-química da polpa de noni (Morinda citrifolia L.). In: CONGRESSO BRASILEIRO DE FRUTICULTURA, 20., 2008. [Vitória]. Anais... [Vitória]: [Embrapa], 2008.

BARTH, A.D.; OKO, R.J. Abnormal morphology of bovine spermatozoa. Ames: Iowa State University Press, 1989. 285p.

BOX, G.E.P.; COX, D.R. An analysis of transformations. J. R. Statist. Soc. B, v.26, p.211252,1964

CÂMARA， D.R.; GUERRA， M.M.P. Ram semen cooling and criopreservation: damage inherent to technique and influence of medium supplementation with antioxidants at the sperm quality. Rev. Bras. Reprod. Anim., v.35, p.33-40, 2011. 
CHAN-BLANCO, Y.; VAILLANT, F.; PEREZ, A.M. et al. The noni fruit (Morinda citrifolia L.): a review of agricultural research, nutritional and therapeutic properties. J. Food Comp. Anal., v.19, p.645-654, 2006.

CORANDIN, E.M.; PEREIRA, P.H.S.; PRADO, T.F. et al. Efeito da cisteína adicionada ao meio diluente sobre a cinética de espermatozóides ovinos após descongelamento. Biochem. Biotec. Rep., v.2, p.21-24, 2013.

FONSECA, J.F.; TORRES, C.A.A.; MAFFILI, V.V. et al. The hypoosmotic swelling test in fresh goat spermatozoa. Anim. Reprod., v.2, p.139-144, 2005.

GARNER, D.L.; JOHNSON, L.A. Viability assessment of mammalian sperm using SYBR-14 and propidium iodide. Biol. Reprod., v.53, p.276284, 1995

GILLAN, L.; EVANS, G.; MAXWELL, W. Capacitation status and fertility of fresh and frozen-thawed ram spermatozoa. Reprod. Fertil. Dev., v.9, p.481-488, 1997.

GONÇALVES, P.B.D.; FIGUEIREDO, J.R.; FREITAS, V.J.F. Biotécnicas aplicadas à reprodução animal. 2.ed. São Paulo: Roca, 2008. $408 \mathrm{p}$.

GREEN, C.E.; WATSON, P.F. Comparison of the capacitation-like state of cooled boar spermatozoa with true capacitation. Reprodução, v.122, p.889-898, 2001.

GUERRA, M.M.P.; EVANS, G.; MAXWELL, W.M.C. Role of oxidants and antioxidants in andrology: a review. Rev. Bras. Reprod. Anim., v.28, p.187, 2004.

HANCOCK, J.L. The morphology of boar spermatozoa. J. R. Microsc. Soc., v.76, p.84-97, 1956.

HENRY, M.; NEVES, J.P. Manual para exame andrológico e avaliação de sêmen animal. 2.ed. Belo Horizonte: CBRA, 1998. 49p.

HENRY, M.; NEVES, J.P.; JOBIM, M.I.M. Manual para exame andrológico e avaliação de sêmen animal. 3.ed. Belo Horizonte: CBRA, 2013. 104p.

KUTVOELGYI, G. Use of morinda citrifolia (noni) extract for improving sperm preservation. WO 2008032132 A2. Brazil, 2008.
LAPENNA, D.; CIOFANI, G.; PIERDOMENICO, S.D. et al. Reaction conditions affecting the relationship between thiobarbituric acid reactivity and lipid peroxidesin human plasma. Free Radic. Biol. Med., v.31, p.331-335, 2001.

MAIA, M.S.; BICUDO, S.D.; AZEVEDO, H.C. et al. Efeito da adição de lauril sulfato de sódio (OEP) ao diluidor na viabilidade do sêmen congelado de ovinos Santa Inês. Vet. Zootec., v.15, p.521-530, 2008.

MAIA, M.S.; BICUDO, S.D.; AZEVEDO, H.C. et al. Motility and viability of ram sperm cryopreserved in a Tris-egg yolk extender supplemented with anti-oxidants. Small Ruminant Res., v.85, p.85-90, 2009.

NASCIMENTO, A.L.C.; SANTOS, A.D.F.; AZEVEDO, H.C. et al. Antioxidant activity of aqueous extract of Noni in dilutent for ram semen cryopreservation. Bol. Ind. Anim., v.73, p.68-74, 2016.

NEVES, J.P.; NUNES, J.F.J.; MORAES, C.F. et al. Inseminação artificial em pequenos ruminantes. In: GONÇALVES, P.B.D.; FIGUEIREDO, J.R.; FIGUEIREDO FREITAS, V.J. (Eds.). Biotécnicas aplicadas à reprodução animal. São Paulo: Roca, 2008. p.57-81.

PEIXOTO, A.L.V.A.; CÂMARA, D.R. et al. Incubation time effect after thawing on the viability of cryopreserved ovine sperm with TrisYolk supplemented with vitamin $\mathrm{C}$ and Trolox. Ciênc. Vet. Trop., v.11, p.16-24, 2008.

PENITENTE-FILHO, J.M.; OLIVEIRA, F.A.; JIMENEZ, C.R. et al. Association of vitamin E with rapid thawing on goat semen. Sci. World J., v.2014, p.1-5, 2014.

PEREZ, L.J.; VALCARCEL, A.; DE LAS HERAS, M.A. et al. In vitro capacitation and induction of acrosomal exocytosis in ram spermatozoa as assessed by the chlortetracycline assay. Theriogenology, v.45, p.1037-1046, 1996.

PERIS, S.I.; MORRIER, A.; DUFOUR, M. et al. Cryopreservation of ram semen facilitates sperm DNA damage: relationship between sperm andrological parameters and the sperm chromatin structure assay. J. Androl., v.25, p.224-233, 2004. 
SALAMON, S.; MAXWELL, W. Storage of ram semen. Anim. Reprod. Sci., v.62, p.77-111, 2000.

SANTOS, V.S.; SANTOS, A.D.F.; OLIVEIRA, D.A. et al. Adição da polpa liofilizada do Noni em diluente para congelação de sêmen sobre a integridade da membrana plasmática de espermatozoides ovinos. Sci. Plena, v.11, 2015.

SAS STAT user's guide: statistics, version 9.1. Cary: SAS, 2002.

SICHERLE, C.C. Viabilidade e capacitação espermáticas, geração de peróxido de hidrogênio (H2O2) e lipoperoxidação no sêmen ovino adicionado de plasma seminal ou antioxidante após a criopreservação. 2007. 73f. (Mestrado). Faculdade de Medicina Veterinária e Zootecnia, Universidade Estadual Paulista, Botucatu, SP.

SILVA, J.C. Criopreservação de sêmen ovino com diferentes concentrações espermáticas associado ou não com ácido ascórbico. 2013. 52f. (Doutorado). Programa de Pós-graduação em Zootecnia, Universidade Federal de Viçosa, Viçosa, MG.
SILVA, L.R.; MEDEIROS, P.V.Q.; LEITE, G.A. et al. Characterization of Morinda citrifolia L. (noni) fruit. Rev. Cuban. Plantas Med., v.17, p.93-100, 2012.

SILVA, M.I.G.; AQUINO-NETO, M.R. et al. Central nervous system activity of acute administration of isopulegol in mice. Pharmacol. Biochem. Behav., v.88, p.141-147, 2007.

THOMAS, A.; MEYERS, S.A.; BALL, B. Capacitation-like changes in equine spermatozoa following cryopreservation. Theriogenology, v.65, p.1531-1550, 2006.

WATSON, P. Recent developments and concepts in the cryopreservation of spermatozoa and the assessment of their post-thawing function. Reprod. Fertil. Dev., v.7, p.871-891, 1995.

WATSON, P. The causes of reduced fertility with cryopreserved semen. Anim. Reprod. Sci., v.60, p.481-492, 2000. 